\title{
Temporal Variations on Soil Salinity and Cation Displacement at Saemangeum and Yeongsangang Reclaimed Tidal Lands
}

\author{
Sanghun Lee*, Hui-Su Bae, Hong-Kyu Kim, Tae-Hwan Noh, Geon-Hwi Lee \\ Reclaimed Land Agricultural Division, Department of Rice and Winter Cereal Crop, National Institute of Crop \\ Science, RDA, Iksan, Republic of Korea \\ Email: sangusa@korea.kr
}

Received 6 August 2014; revised 12 September 2014; accepted 24 September 2014

Copyright @ 2014 by authors and Scientific Research Publishing Inc.

This work is licensed under the Creative Commons Attribution International License (CC BY). http://creativecommons.org/licenses/by/4.0/

(c) (i) Open Access

\section{Abstract}

Soil salinity at reclaimed tidal land in Korea is highly variable and depending on soil characteristics and weather conditions. The objective of this study was to evaluate the temporal changes on soil salinity and the relationships between soil salinity and salinity parameters in reclaimed tidal lands. Soil samples were periodically collected at $0-20 \mathrm{~cm}$ (surface) and $20-40 \mathrm{~cm}$ (subsurface) layer at Saemangeum (sandy loam) and Yeongsangang (silty loam) reclaimed tidal land. Electrical conductivity (EC) had a wide range from 0.0 to $34.3 \mathrm{dS} \cdot \mathrm{m}^{-1}$ during the experimental period. The average soil EC was 6.4 and $3.4 \mathrm{dS} \cdot \mathrm{m}^{-1}$ at Saemangeum and Yeongsangang reclaimed tidal land, respectively. Soluble sodium concentration had great variations and it was the most important single factor for temporal variations of soil EC regardless of soil textural properties. Calcium concentration was negatively correlated with soil EC and soluble sodium. Soil exchangeable sodium percentage (ESP) was estimated as a function of soil sodium adsorption ratio (SAR) and a linear regression model (ESP = 6.075 (SAR) + 0.677 for Saemangeum and ESP = 3.925 (SAR) + 0.421 for Yeongsangang reclaimed tidal soil) was suggested for predicting soil ESP from soil SAR. The characteristics of reclaimed tidal lands had different shares of saline and sodic properties during the experimental period. Saemangeum reclaimed tidal soil was highly characterized by sodium, but the effect of sodium on Yeongsangang soil was less pronounced. Our results indicate that persistent monitoring and modeling on soil salinity at reclaimed tidal soil is fundamental and the results can provide some useful information for deciding management plans for diverse utilization or to reduce salt damage for stable crop production at reclaimed tidal land.

\section{Keywords}

Reclaimed Tidal Land, Soil Salinity, Temporal Variation, Exchangeable Sodium Percentage, Sodium

\footnotetext{
*Corresponding author.
}

How to cite this paper: Lee, S., Bae, H.-S., Kim, H.-K., Noh, T.-H. and Lee, G.-H. (2014) Temporal Variations on Soil Salinity and Cation Displacement at Saemangeum and Yeongsangang Reclaimed Tidal Lands. Journal of Agricultural Chemistry and Environment, 3, 121-129. http://dx.doi.org/10.4236/jacen.2014.34014 


\section{Adsorption Ratio}

\section{Introduction}

Reclaimed tidal lands that locate mainly in west and south coastal areas of Korean peninsula are approximately 350,000 ha, which occupy about $21 \%$ of arable lands for crop production [1]. The importance of reclaimed tidal lands is gradually increasing in Korea because stable food production is fundamental in response to increasing world population and improvement of living standard [2]. However, the crop production at reclaimed tidal lands is limited due to its high soil salinity level [3].

It is projected that salt damages in reclaimed tidal land is likely to increase with future climate change scenarios such as the rise in sea level and temperature that will subsequently increase evaporation rate and salt accumulation in root zone. It is well reported that salinity level in agricultural soils depends on the variations of many factors such as soil texture, plant growth, quality of irrigation water, hydraulic conductivity, and irrigation system in place [4]-[6]. Therefore, the continuous monitoring on soil salinity can be used to avoid crop yield loss and to manage salinity level in root zone under crop threshold level, which results in diverse utilization of reclaimed tidal land for stable crop production.

The dynamic characteristics of soil salts depend on environmental factors such as nature of soils, the amount and type of soluble salts, and local hydrological conditions [7] [8]. The understanding of predominant salt type is critical because individual ions may affect on soil properties and the possibility that ions may be toxic to crops [9]. Soils with different type and amount of salts show different soil properties, which results in different management practices. The most widely used parameter to evaluate soil salinity is electrical conductivity (EC) that is measuring of salt concentration in soil water [10]. Soil EC is influenced by the type and amount of soluble salts. Soluble salts can easily be leached out of the top surface soil under good drainage conditions. Therefore, management might be based on intercepting water coming into the high EC soils. On the other hand, the presence of excess sodium $(\mathrm{Na})$ can disperse soil particles, which results in poor soil structure with unfavorable physical properties such as reduced aggregate stability, retarded water infiltration, and making plant growth stunted [7]. The content of Na in soils is evaluated either through its exchangeable sodium percentage (ESP) or sodium adsorption ratio (SAR). High Na soil (sodic soil) is required to replace the excessive $\mathrm{Na}$ from cation exchange sites with calcium (Ca) supplements. Some studies have been reported that gypsum $\left(\mathrm{CaSO}_{4} \cdot 2 \mathrm{H}_{2} \mathrm{O}\right)$ application was effective on salt degradation in reclaimed tidal lands in Korea [11] [12]. The management of soils with high EC and $\mathrm{Na}$ is usually more complicated because $\mathrm{Ca}$ and magnesium $(\mathrm{Mg})$ salts are preferentially leached away and $\mathrm{Na}$ is more slowly leached out and eventually dominates the soil [13]. The management of these soils requires applying Ca supplements followed by desalinization practices of improving the level of water table and soil drainage.

Soil salinity is highly variable by local climate, management practices, and environmental conditions. Reclaimed tidal lands showed the various levels of soil salinity regardless of its establishment time [14]. Therefore, it is necessary to monitor on changes of soil salinity to evaluate and determine the best management practices in reclaimed tidal lands. Although many researchers have assessed the spatial changes of soil salinity at reclaimed tidal lands in Korea [3] [15], there are limited information available on temporal changes of soil salinity in reclaimed tidal lands to help to decide management practices for reducing crop yield loss. Therefore, the objective of this study was to evaluate the temporal changes of soil salinity and generate soil salinity information to be used a part of any management practices or land use plan of reclaimed tidal land.

\section{Materials and Methods}

\subsection{Study Field Characteristics}

Reclaimed tidal lands are salt affected soils that parent material is fluvio-marine deposit soil. Based on soil texture, reclaimed tidal land in Korea can be classified as two categorized soils; 1) sandy loam and 2) silty loam [16] [17]. Therefore, experimental sites were selected at Saemangeum $\left(35^{\circ} 46^{\prime} \mathrm{N}, 126^{\circ} 37^{\prime} \mathrm{E}\right)$ and Yeongsangang $\left(34^{\circ} 38^{\prime} \mathrm{N}, 126^{\circ} 30^{\prime} \mathrm{E}\right)$ reclaimed tidal land and their dominant soil series were Munpo (coarse loamy, mixed, nonacid, mesic, TypicFluvaquents) and Poseung (Fine silty, mixed, non-acid, mesic, Typic Endoaquepts), respec- 
tively. Both sites have a similar EC values (2.4 and $2.7 \mathrm{dS} \cdot \mathrm{m}^{-1}$ ) at soil surface layer on April, 2013. The organic matter (11.6 vs. $\left.2.5 \mathrm{~g} \cdot \mathrm{kg}^{-1}\right)$ and clay content (13\% vs. $\left.2 \%\right)$ at Yeongsangang was markedly greater than in Saemangeum reclaimed tidal land. The physical and chemical properties of experimental site are shown in Table 1.

The experimental sites have a temperate climate regions with the annual mean temperatures were $12.6^{\circ} \mathrm{C}$ and $13.4^{\circ} \mathrm{C}$ at Saemangeum and Yeongsangang reclaimed tidal land, respectively. The average long-term annual precipitation was $1250 \mathrm{~mm}$ at Saemangeum and $1325 \mathrm{~mm}$ at Yeongsangang reclaimed land, on which, about $50 \%$ falls between June and August. Under high soil salinity condition bare patches are observed devoid of any vegetation. Some salt tolerant grass species grown in experimental sites were manually removed by hands.

\subsection{Sample Collection and Analysis}

Three sampling sites were selected at each reclaimed tidal land and three cores of soil samples were taken by a hand spiral auger from surface $(0-20 \mathrm{~cm})$ and sub-surface $(20-40 \mathrm{~cm})$ layer weekly from April to November, 2013. The part of collected soil samples were used for mass water content by oven drying at $110^{\circ} \mathrm{C}$ and the rest of samples were air-dried, passed through a 2-mm sieve, and then used for the chemical analysis. Soil $\mathrm{pH}$ and electrical conductivity (EC) was determined with $\mathrm{pH}$ electrode (Beckman PH1560, USA) and conductivity meter (Orion 162A, USA) from 1:5 soil/water suspension. Soil EC of a saturation paste extract was estimated from the EC using 1:5 soil/water suspension and an estimate of soil texture. Organic matter content was measured by Tyurin method (NIAST, 2000). Cation exchange capacity (CEC) was measured by $1 \mathrm{~N}^{-} \mathrm{NH}_{4} \mathrm{OAc}$ at $\mathrm{pH}$ 7.0. Particle size distribution was conducted by using ASTM 152H hydrometer after dispersion with 5\% sodium hexametaphosphate. Soluble and exchangeable cations were sequentially extracted with distilled water and $1 \mathrm{~N}-\mathrm{NH}_{4} \mathrm{OAc}$ (adjusted $\mathrm{pH}$ 7.0) and quantified by inductively coupled plasma-optical emission spectrometer (Varion Vista-MPX, Australia). Sodium adsorption ratio (SAR) and exchangeable sodium percentage (ESP) are given as:

$$
\begin{gathered}
\mathrm{SAR}=\mathrm{Na}^{+} / \sqrt{\left(\mathrm{Ca}^{2+}+\mathrm{Mg}^{2+}\right) / 2} \\
\mathrm{ESP}=\left(\mathrm{Na}^{+} / \mathrm{CEC}\right) \times 100
\end{gathered}
$$

$\mathrm{Na}^{+}, \mathrm{Ca}^{2+}, \mathrm{Mg}^{2+}=$ exchangeable $\mathrm{Na}^{+}, \mathrm{Ca}^{2+}$, and $\mathrm{Mg}^{2+}$, respectively, in $\mathrm{mmol} \cdot \mathrm{kg}^{-1}$;

$\mathrm{CEC}=$ cation exchangeable capacity, in $\mathrm{mmol} \cdot \mathrm{kg}^{-1}$.

Based on soil EC and ESP values, study soils were classified into four groups: 1) soils with EC $\geq 4 \mathrm{dS} \cdot \mathrm{m}^{-1}$ and ESP $<15 \%$ are designated as saline, 2) soils with EC $<4 \mathrm{dS} \cdot \mathrm{m}^{-1}$ and ESP $\geq 15 \%$ are designated as sodic, 3) soils with EC $\geq 4 \mathrm{dS} \cdot \mathrm{m}^{-1}$ and ESP $\geq 15 \%$ are designated as saline-sodic, and 4) non-salt affected soils [18]. All other soil analysis was conducted based on standard methods by NIAST [19].

\subsection{Statistical Analysis}

The data was statistically analyzed using analysis of variance (ANOVA) with the JMP statistical program (SAS institute ver. 5.0, USA). Means between treatments were compared by least significant difference and TukeyKramer HSD at 95\% level when the F-test was statistically significant.

\begin{tabular}{|c|c|c|c|c|c|c|c|c|c|}
\hline \multirow{2}{*}{$\begin{array}{l}\text { Soil Depth } \\
\text { (cm) }\end{array}$} & \multirow{2}{*}{$\begin{array}{c}\mathrm{pH} \\
(1: 5)\end{array}$} & \multirow{2}{*}{$\begin{array}{c}\text { EC } \\
\left(\mathrm{dS} \cdot \mathrm{m}^{-1}\right)\end{array}$} & \multirow{2}{*}{$\begin{array}{c}\mathrm{OM} \\
\left(\mathrm{g} \cdot \mathrm{kg}^{-1}\right)\end{array}$} & \multirow{2}{*}{$\begin{array}{l}\text { Av. } \mathrm{P}_{2} \mathrm{O}_{5} \\
\left(\mathrm{dS} \cdot \mathrm{m}^{-1}\right)\end{array}$} & \multicolumn{4}{|c|}{ Particle Size Distribution (\%) } & \multirow{2}{*}{$\begin{array}{c}\text { CEC } \\
\left(\mathrm{cmol}^{\left.-\mathrm{kg}^{-1}\right)}\right.\end{array}$} \\
\hline & & & & & Sand & Silt & Clay & Texture & \\
\hline & \multicolumn{9}{|c|}{ 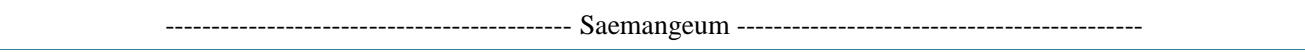 } \\
\hline $0-20$ & 7.9 & 2.4 & 2.5 & 70 & 66 & 33 & 2 & $\mathrm{SL}^{\dagger}$ & 5.8 \\
\hline $20-40$ & 7.7 & 3.3 & 2.0 & 32 & 59 & 39 & 2 & SL & 6.2 \\
\hline $0-20$ & 8.5 & 2.7 & 11.6 & 142 & 27 & 60 & 13 & SiL & 15.0 \\
\hline $20-40$ & 8.7 & 5.8 & 8.1 & 40 & 21 & 65 & 14 & SiL & 15.4 \\
\hline
\end{tabular}

Table 1. Soil physical and chemical properties of study soils at pre-experiment stage.

${ }^{\dagger}$ SL, sandy loam; SiL, silty loam. 


\section{Results and Discussion}

During the experimental period, electrical conductivity (EC) had widely ranged from 0.1 to $34.3 \mathrm{dS} \cdot \mathrm{m}^{-1}$ at Saemangeum and from 0.0 to $8.8 \mathrm{dS} \cdot \mathrm{m}^{-1}$ at Yeongsangang reclaimed tidal land (Table 2). Although EC values at pre-experimental stage showed similar values between surface layers of two locations, the mean EC value of Saemangeum soil was significantly higher $\left(6.4 \mathrm{vs} .3 .4 \mathrm{dS} \cdot \mathrm{m}^{-1}\right)$ than those of Yeongsangang reclaimed tidal soil. The standard deviation of soil EC was significantly greater at Saemangeum, indicating that soil salinity at Saemangeum reclaimed tidal land was more fluctuated. This result is supported that soil EC was highly correlated with soluble $\mathrm{Na}$ contents in soil and standard deviation of soluble $\mathrm{Na}$ at Saemangeum reclaimed tidal soil had considerably higher than those of Yeongsangang reclaimed tidal soil. Although Saemangeum soil showed the less concentration of soluble $\mathrm{Ca}$ and $\mathrm{Mg}$ compared to Yeongsangang, soil EC value at Saemangeum soil was greater than Yeongsangang soil. Soluble Na concentration of surface layer was substantially greater at Saemangeum reclaimed tidal land. This result indicates that the temporal variations of soil salinity were much greater at Saemangeum reclaimed tidal soil. The mean sodium adsorption ratio (SAR) and exchangeable sodium percentage (ESP) values showed that an identical distribution pattern to EC values at both locations. The mean $\mathrm{pH}$ values averaged 7.8 at Saemangeum and 8.1 at Yeongsangang reclaimed tidal land, indicating alkalization level in the study, but the variation in the observed $\mathrm{pH}$ was relatively small compared to other salinity parameters.

Soil EC values were significantly influenced by the interaction between sampling site and depth at Saemangeum (Table 3) and Yeongsangang (Table 4) reclaimed tidal land. Soil EC, soluble Na, SAR and ESP at site 3 of Saemangeum reclaimed tidal land was significantly higher than other two sites. In site 3, soil EC value at surface layer was significantly greater than sub-surface layer, which was attributed to increase in concentration of soluble Na at surface layer. The sub-surface layer showed a similar concentration of soluble Ca and Mg than those of the surface layer, while the concentration of soluble Na at the surface layer were substantially higher at Saemangeum reclaimed tidal soil. These results probably reflect a displacement and accumulation of salts from the lower layer towards soil surface. It is well reported that environmental factors such as soil porosity, quantity of percolation water, nature of the ions present determine the mobility of different ions and their differential spatial behavior [8] [20]. The texture of Saemangeum soil was loamy sand and the hydraulic conductivity was much greater compared to Yeongsangang reclaimed tidal soil [21], which indicate that the upward movement of water and salts was much greater at Saemangeum reclaimed tidal soil. The standard deviations of soluble Na were also much greater, which suggest that soluble Na was the primary ion on the variations of soil EC. Contrary to Saemangeum soil, the EC value of the sub-surface layer at Yeongsangang reclaimed tidal soil was lower compared to the surface layer (Table 4). The composition of soluble ions had a similar pattern that the concentration of soluble $\mathrm{Ca}$ and $\mathrm{Mg}$ were greater at the surface layer, while the soluble $\mathrm{Na}$ concentration was significantly greater at sub-surface layer than the surface layer in all sites.

Table 2. The mean values and standard deviation (S.D.) of Saemangeum and Yeongsangang reclaimed tidal soil during the experimental periods.

\begin{tabular}{|c|c|c|c|c|c|c|c|c|}
\hline & \multirow{2}{*}{$\begin{array}{c}\mathrm{MWC}^{\dagger} \\
(\%)\end{array}$} & \multirow{2}{*}{$\begin{array}{c}\mathrm{pH} \\
(1: 5)\end{array}$} & \multirow{2}{*}{$\begin{array}{c}\mathrm{EC} \\
\left(\mathrm{dS} \cdot \mathrm{m}^{-1}\right)\end{array}$} & \multicolumn{3}{|c|}{ Soluble cations $\left(\mathrm{cmol} \cdot \mathrm{kg}^{-1}\right)$} & \multirow{2}{*}{ SAR } & \multirow{2}{*}{$\begin{array}{l}\text { ESP } \\
(\%)\end{array}$} \\
\hline & & & & $\mathrm{Ca}$ & $\mathrm{Mg}$ & $\mathrm{Na}$ & & \\
\hline & \multicolumn{8}{|c|}{ 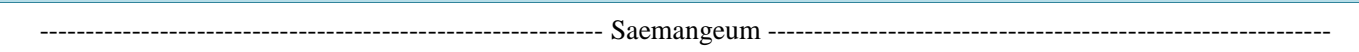 } \\
\hline Minimum & $8.5(18.6)$ & $6.1(6.5)$ & $0.1(0.1)$ & $0.03(0.05)$ & $0.10(0.18)$ & $0.10(0.15)$ & $0.6(1.3)$ & $4.4(9.0)$ \\
\hline Maximum & $36.3(38.5)$ & $9.4(9.3)$ & $34.3(31.9)$ & $1.06(0.74)$ & 4.27 (3.89) & 27.59 (19.26) & $9.3(7.5)$ & 61.5 (42.8) \\
\hline Mean & $23.3(25.1)$ & $7.8(7.9)$ & $6.4(6.1)$ & $0.16(0.17)$ & $0.98(0.95)$ & $5.61(4.66)$ & 3.5 (3.8) & $21.5(24.1)$ \\
\hline S.D. & $5.0(2.5)$ & $0.5(0.5)$ & $8.8(7.1)$ & $0.15(0.13)$ & $0.93(0.57)$ & $7.70(4.92)$ & $2.8(1.3)$ & $14.3(8.1)$ \\
\hline Minimum & $9.7(7.0)$ & $7.3(7.1)$ & $0.0(0.1)$ & $0.05(0.08)$ & $0.21(0.16)$ & $0.16(0.27)$ & $0.2(1.3)$ & $0.6(4.4)$ \\
\hline Maximum & $48.0(45.2)$ & $9.1(9.1)$ & $8.8(10.4)$ & $0.73(0.88)$ & $5.47(5.98)$ & 16.89 (17.64) & $4.7(6.4)$ & $20.1(26.5)$ \\
\hline Mean & $23.1(26.7)$ & $8.1(8.1)$ & $3.4(4.9)$ & $0.40(0.31)$ & $1.76(1.36)$ & $3.02(4.53)$ & $2.2(3.5)$ & $9.3(14.0)$ \\
\hline S.D. & $6.4(7.1)$ & $0.4(0.5)$ & $0.4(0.5)$ & $0.13(0.13)$ & $1.08(1.23)$ & $1.74(2.17)$ & $0.7(1.1)$ & $3.4(4.8)$ \\
\hline
\end{tabular}

Values in parenthesis are values from sub-surface layer $(20-40 \mathrm{~cm}){ }^{\dagger}$ MWC, mass water content; SAR, sodium adsorption ratio; ESP, exchangeable sodium percentage. 
Table 3. The mean values of soil physical and chemical properties of Saemangeum reclaimed tidal soil.

\begin{tabular}{|c|c|c|c|c|c|c|c|c|}
\hline \multirow{2}{*}{ Location } & \multirow{2}{*}{$\begin{array}{l}\text { Depth } \\
\text { (cm) }\end{array}$} & \multirow{2}{*}{$\begin{array}{c}\mathrm{MWC}^{\dagger} \\
(\%)\end{array}$} & \multirow{2}{*}{$\begin{array}{c}\mathrm{pH} \\
(1: 5)\end{array}$} & \multirow{2}{*}{$\begin{array}{c}\text { EC } \\
\left(\mathrm{dS} \cdot \mathrm{m}^{-1}\right)\end{array}$} & \multicolumn{2}{|c|}{ Soluble $\left(\mathrm{cmol} \cdot \mathrm{kg}^{-1}\right)$} & \multirow{2}{*}{ SAR } & \multirow{2}{*}{$\begin{array}{l}\text { ESP } \\
(\%)\end{array}$} \\
\hline & & & & & $\mathrm{Ca}$ & $\mathrm{Na}$ & & \\
\hline \multirow[t]{2}{*}{ Site 1} & $0-20$ & 22.3 & 7.6 & 1.0 & 0.09 & 0.33 & 1.1 & 7.0 \\
\hline & $20-40$ & 24.0 & 8.1 & 1.1 & 0.10 & 0.55 & 2.5 & 15.5 \\
\hline \multirow[t]{2}{*}{ Site 2} & $0-20$ & 23.1 & 7.9 & 1.5 & 0.09 & 1.39 & 3.3 & 19.2 \\
\hline & $20-40$ & 25.3 & 7.7 & 4.0 & 0.12 & 3.27 & 3.9 & 24.7 \\
\hline \multirow[t]{2}{*}{ Site 3} & $0-20$ & 24.5 & 7.8 & 15.7 & 0.30 & 14.11 & 6.0 & 38.1 \\
\hline & $20-40$ & 26.2 & 8.0 & 12.8 & 0.28 & 10.16 & 5.0 & 32.0 \\
\hline \multicolumn{2}{|c|}{ p-value } & $<0.0001$ & $<0.0001$ & $<0.0001$ & $<0.0001$ & $<0.0001$ & $<0.0001$ & $<0.0001$ \\
\hline \multicolumn{2}{|c|}{$L S D_{0.05}$} & 1.2 & 0.1 & 1.7 & 0.04 & 1.24 & 0.4 & 2.1 \\
\hline \multicolumn{2}{|l|}{ Site 1} & 23.2 & 7.9 & 1.0 & 0.10 & 0.44 & 1.8 & 11.3 \\
\hline \multicolumn{2}{|l|}{ Site 2} & 24.2 & 7.8 & 2.7 & 0.11 & 2.33 & 3.6 & 21.9 \\
\hline \multicolumn{2}{|l|}{ Site 3} & 25.3 & 7.9 & 14.3 & 0.29 & 12.63 & 5.5 & 35.1 \\
\hline \multicolumn{2}{|c|}{ p-value } & $<0.0001$ & 0.0666 & $<0.0001$ & $<0.0001$ & $<0.0001$ & $<0.0001$ & $<0.0001$ \\
\hline \multicolumn{2}{|c|}{$L S D_{0.05}$} & 0.9 & $N S$ & 1.2 & 0.03 & 0.96 & 0.3 & 1.7 \\
\hline & $0-20$ & 23.3 & 7.8 & 6.1 & 0.16 & 5.61 & 3.5 & 21.5 \\
\hline & $20-40$ & 25.1 & 7.9 & 6.4 & 0.17 & 4.66 & 3.8 & 24.1 \\
\hline \multicolumn{2}{|c|}{ p-value } & $<0.0001$ & 0.0012 & 0.668 & 0.5962 & 0.1857 & 0.0715 & 0.0441 \\
\hline \multicolumn{2}{|c|}{$L S D_{0.05}$} & 0.7 & 0.1 & NS & NS & NS & NS & 2.5 \\
\hline
\end{tabular}

${ }^{\dagger} \mathrm{MWC}$, mass water content; SAR, sodium adsorption ratio; ESP, exchangeable sodium percentage.

Table 4. The mean values of soil physical and chemical properties of Yeongsangang reclaimed tidal soil.

\begin{tabular}{|c|c|c|c|c|c|c|c|c|}
\hline \multirow{2}{*}{ Location } & \multirow{2}{*}{$\begin{array}{c}\text { Depth } \\
\text { (cm) }\end{array}$} & \multirow{2}{*}{$\begin{array}{c}\mathrm{MWC}^{\dagger} \\
(\%)\end{array}$} & \multirow{2}{*}{$\begin{array}{c}\mathrm{pH} \\
(1: 5)\end{array}$} & \multirow{2}{*}{$\begin{array}{c}\mathrm{EC} \\
\left(\mathrm{dS} \cdot \mathrm{m}^{-1}\right)\end{array}$} & \multicolumn{2}{|c|}{ Soluble $\left(\mathrm{cmol} \mathrm{kg}^{-1}\right)$} & \multirow{2}{*}{ SAR } & \multirow{2}{*}{$\begin{array}{l}\text { ESP } \\
(\%)\end{array}$} \\
\hline & & & & & $\mathrm{Ca}$ & $\mathrm{Na}$ & & \\
\hline \multirow[t]{2}{*}{ Site 1} & $0-20$ & 28.0 & 8.0 & 2.9 & 0.39 & 2.57 & 2.6 & 11.2 \\
\hline & $20-40$ & 33.6 & 8.1 & 4.6 & 0.35 & 4.01 & 4.1 & 17.1 \\
\hline \multirow[t]{2}{*}{ Site 2} & $0-20$ & 20.6 & 8.3 & 3.8 & 0.39 & 3.08 & 2.2 & 9.1 \\
\hline & $20-40$ & 25.4 & 8.3 & 5.6 & 0.25 & 4.93 & 3.0 & 14.3 \\
\hline \multirow[t]{2}{*}{ Site 3} & $0-20$ & 20.6 & 7.9 & 3.3 & 0.41 & 3.42 & 1.9 & 7.5 \\
\hline & $20-40$ & 21.1 & 8.0 & 4.6 & 0.33 & 4.65 & 2.8 & 10.6 \\
\hline \multicolumn{2}{|r|}{ p-value } & $<0.0001$ & $<0.0001$ & $<0.0001$ & $<0.0001$ & $<0.0001$ & $<0.0001$ & $<0.0001$ \\
\hline \multicolumn{2}{|r|}{$L S D_{0.05}$} & 1.5 & 0.1 & 0.5 & 0.05 & 0.8 & 0.3 & 1.3 \\
\hline \multicolumn{2}{|l|}{ Site 1} & 30.8 & 8.0 & 3.8 & 0.37 & 3.29 & 3.3 & 14.2 \\
\hline \multicolumn{2}{|l|}{ Site 2} & 23.0 & 8.3 & 4.7 & 0.32 & 4.00 & 2.9 & 11.7 \\
\hline \multicolumn{2}{|l|}{ Site 3} & 20.9 & 7.9 & 4.0 & 0.37 & 4.04 & 2.3 & 9.1 \\
\hline \multicolumn{2}{|r|}{ p-value } & $<0.0001$ & $<0.0001$ & $<0.0001$ & 0.0072 & 0.0197 & $<0.0001$ & $<0.0001$ \\
\hline \multicolumn{2}{|r|}{$L S D_{0.05}$} & 1.2 & 0.1 & 0.4 & 0.04 & 0.59 & 0.3 & 1.1 \\
\hline & $0-20$ & 23.1 & 8.1 & 3.4 & 0.40 & 3.02 & 2.2 & 9.3 \\
\hline & $20-40$ & 26.7 & 8.1 & 4.9 & 0.31 & 4.53 & 3.5 & 14.0 \\
\hline \multicolumn{2}{|r|}{ p-value } & $<0.0001$ & 0.1577 & $<0.0001$ & $<0.0001$ & $<0.0001$ & $<0.0001$ & $<0.0001$ \\
\hline \multicolumn{2}{|r|}{$L S D_{0.05}$} & 1.2 & $N S$ & 0.3 & 0.03 & 0.46 & 0.2 & 0.9 \\
\hline
\end{tabular}

${ }^{\dagger}$ MWC, mass water content; SAR, sodium adsorption ratio; ESP, exchangeable sodium percentage. 
The mean SAR and ESP values showed an identical distribution pattern to the mean EC values at Yeongsangang reclaimed tidal land (Table 4). Many studies have shown that there is a correlation between EC and SAR due to its close correlation between both parameters [8] [22]. The relationship between SAR and ESP of Saemangeum and Yeongsangang reclaimed tidal soil is shown in Figure 1. Many researchers have been assessed to predict the relationship between soil ESP and SAR because the determination of soil ESP is necessary to analyze soil cation exchange capacity (CEC), which is time consuming laboratory test [23] [24]. There were linear regressions between soil SAR and ESP in ESP $=6.075(\mathrm{SAR})+0.677\left(\mathrm{R}^{2}=0.947\right)$ and ESP $=3.925(\mathrm{SAR})+$ $0.421\left(R^{2}=0.895\right)$ for Saemangeum and Yeongsangang reclaimed tidal land, respectively. Soil ESP values were much greater compared to soil SAR at both locations. This result is probably due to the characteristics of reclaimed tidal lands which contain high concentration of soil exchangeable Mg. The previous study suggested that proportionality coefficient from the relationship between ESP and SAR is related to the Gapon equation [25]. The data indicates that the SAR value of Saemangeum soil will result in a 55\% more increase in ESP than Yeongsangang soil. These unique relationships between soil ESP and SAR were reasonable since the relationship is related to intrinsic soil properties [26].

Electrical conductivity is influenced by physical and chemical properties of soil including soluble salts, soil water content, bulk density, temperature, and organic matter content [27]. The salt compositions were correlated in an attempt to establish any relationship between soluble and exchangeable cations and their influence on the EC values (Table 5). The results showed that a higher linearity for soluble $\mathrm{Na}(\mathrm{r}=0.937)$ and total sum of soluble cations $(r=0.9391)$ were obtained from Saemangeum reclaimed tidal land. These results indicate that soluble cations, especially soluble $\mathrm{Na}$, have the most influencing factor on soil EC. This result was corresponding with the results that Na had the greatest influence on soil EC than other cations [8]. The data showed that $\mathrm{K}$ and Mg values were widely dispersed and had a relatively low correlation coefficient value regardless of soluble and exchangeable forms. Even though Ca was not a predominant form of soil salts, there were a negatively correlation between exchangeable $\mathrm{Ca}$ and other salt compositions. It is reported that $\mathrm{Ca}$ ion competes for the exchange sites on soil surface by $\mathrm{Na}$ ion so that increasing the Ca concentration reduces the concentration of $\mathrm{Na}$ [28]. These results indicate that the supplement of Ca ion may improve soil salinity at reclaimed tidal lands.

The data of this study showed that soil EC and ESP values were highly fluctuated during the experimental period, which resulted in different shares of saline and sodic properties of experimental soils (Table 6). For example, the $66.7 \%$ and $88.7 \%$ of Saemangeum reclaimed tidal soil was salt-affected at surface and sub-surface layer, respectively. Salt-affected Saemangeum soils had characteristics of sodic or saline-sodic soils, indicating that

Table 5. Results of the spearman rank correlations between EC and saline parameters of Saemangeum reclaimed tidal soils.

\begin{tabular}{|c|c|c|c|c|c|c|c|c|c|c|c|c|}
\hline & Sol. & Sol. & Sol. & Sol. & Exch. & Exch. & Exch. & \multirow{2}{*}{$\begin{array}{c}\text { Exch. } \\
\mathrm{Na}\end{array}$} & \multirow{2}{*}{ SAR } & \multirow{2}{*}{ ESP } & \multirow{2}{*}{$\sum$ sol. } & \multirow{2}{*}{$\sum$ Exch } \\
\hline & $\mathrm{Ca}$ & K & $\mathrm{Mg}$ & $\mathrm{Na}$ & $\mathrm{Ca}$ & $\mathrm{K}$ & $\mathrm{Mg}$ & & & & & \\
\hline EC & 0.715 & 0.649 & 0.791 & 0.937 & -0.674 & 0.581 & 0.540 & 0.879 & 0.819 & 0.879 & 0.939 & 0.862 \\
\hline Sol. Ca & & 0.540 & 0.529 & 0.768 & -0.640 & 0.705 & 0.056 & 0.953 & 0.977 & 0.953 & 0.757 & 0.694 \\
\hline Sol. K & & & 0.809 & 0.686 & -0.442 & 0.532 & 0.390 & 0.609 & 0.570 & 0.609 & 0.733 & 0.631 \\
\hline Sol. Mg & & & & 0.795 & -0.492 & 0.403 & 0.537 & 0.656 & 0.584 & 0.656 & 0.844 & 0.714 \\
\hline Sol. Na & & & & & -0.660 & 0.606 & 0.484 & 0.862 & 0.816 & 0.862 & 0.996 & 0.826 \\
\hline Exch. Ca & & & & & & -0.383 & -0.342 & -0.662 & -0.687 & -0.662 & -0.653 & -0.445 \\
\hline Exch. K & & & & & & & 0.170 & 0.732 & 0.723 & 0.732 & 0.599 & 0.695 \\
\hline Exch. Mg & & & & & & & & 0.286 & 0.139 & 0.286 & 0.501 & 0.674 \\
\hline Exch. Na & & & & & & & & & 0.980 & 0.985 & 0.857 & 0.851 \\
\hline SAR & & & & & & & & & & 0.980 & 0.806 & 0.747 \\
\hline ESP & & & & & & & & & & & 0.857 & 0.851 \\
\hline$\sum$ Sol. & & & & & & & & & & & & 0.832 \\
\hline
\end{tabular}

$\sum$ sol. and $\sum$ Exch. denote summation of soluble and exchangeable cations $(\mathrm{Ca}+\mathrm{K}+\mathrm{Mg}+\mathrm{Na})$ concentration, respectively. 


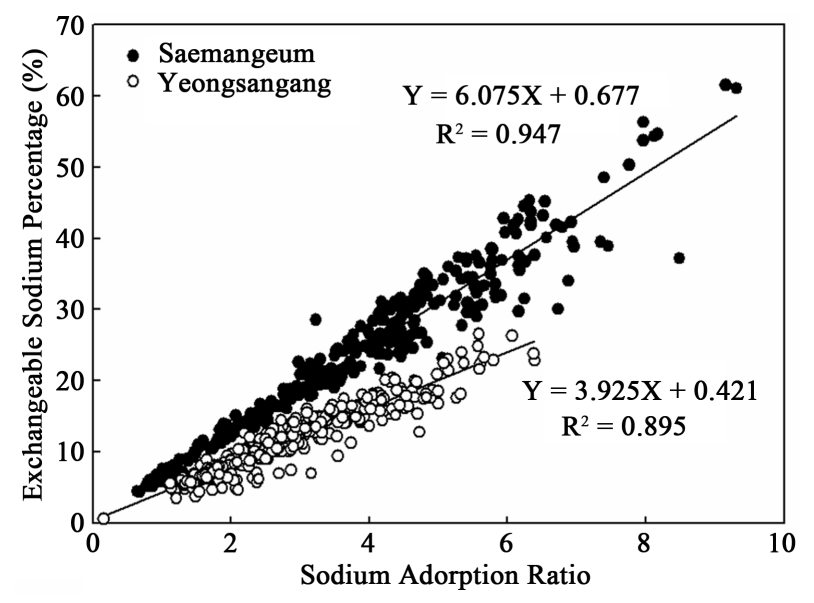

Figure 1. The relationship between sodium adsorption ratio and exchangeable sodium percentage of Saemangeum and Yeongsangang reclaimed tidal soil.

Table 6. Percentages of soil salinity classification in the study soil.

\begin{tabular}{|c|c|c|c|c|c|}
\hline Location & Depth (cm) & Normal $^{\dagger}$ & Saline & Sodic & Saline-Sodic \\
\hline & \multicolumn{5}{|c|}{-------------------------------- \% ------------------------------- } \\
\hline \multirow[t]{2}{*}{ Saemangeum } & $0-20$ & 33.3 & 0.0 & 32.1 & 34.6 \\
\hline & $20-40$ & 11.3 & 0.0 & 48.4 & 40.3 \\
\hline \multirow[t]{2}{*}{ Yeongsangang } & $0-20$ & 63.9 & 31.0 & 3.2 & 1.9 \\
\hline & $20-40$ & 13.9 & 44.3 & 2.5 & 39.2 \\
\hline
\end{tabular}

${ }^{\dagger}$ Normal (EC $<4 \mathrm{dS} \cdot \mathrm{m}^{-1}$, ESP $<15 \%$ ), Saline (EC $\geq 4 \mathrm{dS} \cdot \mathrm{m}^{-1}$, ESP $<15 \%$ ), Sodic (EC $<4 \mathrm{dS} \cdot \mathrm{m}^{-1}$, ESP $\geq 15 \%$ ), Saline-sodic (EC $\geq$ $\left.4 \mathrm{dS} \cdot \mathrm{m}^{-1}, \mathrm{ESP} \geq 15 \%\right)$.

Saemangeum soils were usually associated with high amounts of Na salt. These results were probably due to the characteristics of Saemangeum soil that has high contents of soluble Na, low values of cation exchange capacity and clay content. Contrary to Saemangeum soil, the characteristics of sodic or saline-sodic soils were occasionally found in the surface layer at Yeongsangang reclaimed tidal land. The percentage of non-salt affected characteristics at Yeongsangang soil was much greater (63.9\% vs. $13.9 \%$ ) at the surface layer compared to the subsurface layer. The percentage of normal soils at sub-surface layer was decreased and showed the predominant forms of saline and saline-sodic characteristics at sub-surface layer. The soil with higher levels of Na restricts water-holding capacity, prevent flocculation of soil particles and prevent water penetration [29]. Thus, the less water penetration will become more sodic or saline-sodic properties. The results of these salinity classification showed that Saemangeum and Yeongsangang reclaimed tidal soils had a different characteristic of soil salinity during the growing season.

\section{Conclusion}

The results of this study showed that there was great correlation between soil EC and soluble sodium content of reclaimed tidal soils regardless of soil texture. Soil ESP can be estimated from soil SAR due to the good linear regressions between soil ESP and SAR at both Saemangeum and Yeongsangang reclaimed tidal soils. Saemangeum and Yeongsangang soils had different characteristics of saline and/or sodic soils during the growing season. Saemangeum soils were associated with high amounts of sodium, but the effect of sodium on Yeongsangang soil was less pronounced. The data of this study indicated that any future management practice or land use plan at Saemangeum and Yeongsangang reclaimed tidal lands should be considered characteristics of soil salinity. 


\section{Acknowledgements}

This study was carried out with the support of "Cooperative Research Program for Agriculture Science \& Technology Development (Project No. PJ010258)” Rural Development Administration, Republic of Korea.

\section{References}

[1] Lee, K.B., Hwang, S.W., Kim, H.K., Kang, J.G., Bae, H.S., Lee, S.H and Park, K.H. (2013) Soil Characteristic Assessment of Large-Scale Reclaimed Land and Their Management Plan. Society of Agricultural Research in Reclaimed Land, 11, 15-34.

[2] United Nations (2013) World Population Prospects: The 2012 Revision. New York. http://www.un.org/en/development/desa/population/

[3] Sohn, Y.M., Jeon, G.J., Song, J.D., Lee, J.H. and Park, M.E. (2009) Effect of Spatial Soil Salinity Variation on the Growth of Soiling and Forage Crops Seeded at the Newly Reclaimed Tidal Lands in Korea. Korean Journal of Soil Science and Fertilizer, 42, 179-186.

[4] Larson, W.E. and Robert, P.C. (1991) Farming by Soil. In: Lal, R. and Pierce, F.J., Eds., Soil Management for Sustainability, Soil Water Conservation Society, Ankeny, 103-112.

[5] Liu, G.M., Yang, J.S., He, L.D., Lv, Z.Z., Shao, H.B. and Yu, S.P. (2013) Salt Dynamics in Soil Profiles during LongTerm Evaporation under Different Groundwater Conditions. Plant and Biosystems, 147, 1211-1218. http://dx.doi.org/10.1080/11263504.2013.862314

[6] Pankova, Y., Konyushkova, M. and Luo, G. (2010) Effect of Climate on Soil Salinity in Subboreal Deserts of Asia. 2010 World Congress of Soil Science, Brisbane.

[7] Brady, N.C. and Weil, R.R. (2007) The Nature and Properties of Soils. 14th Edition, Prentice Hall, Lebanon.

[8] Hernandez Bastida, J.A., Vela De Oro, N. and Ortiz Silla, R. (2004) Electrolytic Conductivity of Semiarid Soils (Southeastern Spain) in Relation to Ion Composition. Arid Land Resource Management, 18, 265-281. http://dx.doi.org/10.1080/15324980490451348

[9] Lee, S., Chung, D.Y., Hwang, S.W., Lee, K.B., Yang, C.H. and Kim, H.K. (2012) Hydraulic Property and Solute Breakthrough from Salt Accumulated Soils under Various Head Pressures. Korean Journal of Soil Science and Fertilizer, 45, 717-724. http://dx.doi.org/10.7745/KJSSF.2012.45.5.717

[10] Bower, C.A. and Wilcox, L.V. (1965) Soluble Salts. In: Black, C.A., et al., Methods of Soil Analysis, American Society of Agronomy, Madison, 933-940.

[11] Baek, S.H., Lee, S.U., Lim, H.B., Kim, D.G. and Kim, S.J. (2009) Influence of Gypsum, Popped Rice Hulls and Zeolite on Contents of $\mathrm{Ca}^{2+}, \mathrm{Mg}^{2+}, \mathrm{Na}^{+}, \mathrm{K}^{+}$in Reclaimed Tideland Soils in Kyewhado. Korean Journal of Environmental Agriculture, 28, 25-31. http://dx.doi.org/10.5338/KJEA.2009.28.1.025

[12] Koo, J.W., Choi, J.K., Son, J.G. and Lee, K.S. (1999) Analysis of Desalinization Effects on Gypsum Treatments in Reclaimed Tidelands. Journal of Korean Society of Agricultural Engineering, 41, 162-168.

[13] Franzen, D., Wick, A., Augustin, C. and Kalwar, N. (2013) Saline and Sodic Soils. North Dakota State University, Fargo. http://www.ag.ndsu.edu/langdonrec/soil-health

[14] Hwang, S.W., Kang, J.G., Lee, K.D., Lee, K.B., Park, K.H. and Chung, D.Y. (2012) Division of Soil Properties in Reclaimed Land of the Mangyeong and Dongjin River Basin and Their Agricultural Engineering Management. Korean Journal of Soil Science and Fertilizer, 45, 444-450. http://dx.doi.org/10.7745/KJSSF.2012.45.3.444

[15] Jeong, J.H., Kang, J.G., Lee, K.D., Gil, G.H., Lee, J.H., Hwang, S.W. and Kim, S.J. (2009) Mapping of Salt Concentration in Saemangeum Reclaimed Land. Korean Journal of Soil Science and Fertilizer, 2009 Annual Meeting, 35.

[16] Jeong, J.H., Choi, J.W., Kang, J.G., Ryu, J.H., Lee, K.D., Park, W.J. and Hwang, S.W. (2010) Soil Characteristics and Distribution in Reclaimed Saline Land of Southwest Coastal Area of Korea. Korean Society of Soil Science and Fertilizer, 2010 Fall Annual Meeting, 166-167.

[17] Koo, J.W., Choi, J.K. and Son, J.G. (1998) Soil Properties of Reclaimed Tidal Lands and Tidelands of Western Sea Coast in Korea. Korean Journal of Soil Science and Fertilizer, 31, 120-127.

[18] Sposito, G. (2008) The Chemistry of Soils. 2nd Edition, Oxford University Press, New York.

[19] NIAST (2000) Methods of Soil Chemical Analysis. National Institute of Agricultural Science and Technology. Rural Development Administration, Suwon, Korea.

[20] Prathapar, S.A. and Meyer, W.S. (1992) Measurement and Estimation of Capillary Upflow from Water Tables under Maize on Irrigated Soils. Australian Journal of Soil Research, 31, 119-130. http://dx.doi.org/10.1071/SR9930119

[21] Lee, S., Bae, H.S., Lee, S.H., Hwang, S.A., Kang, J.G., Kim, H.K. and Lee, K.B. (2013) Effect of Furrow Irrigation on 
Millet and Sorghum Growth and Soil Salinity at Reclaimed Tidal Lands. Korean Society of Soil Science and Fertilizer, 2013 Fall Meeting, PB-14.

[22] McNeal, B.L., Oster, J.D. and Hatcher, J.T. (1970) Calculation of Electrical Conductivity from Solution Composition Data as an Aid to In-Situ Estimation of Soil Salinity. Soil Science, 110, 405-414.

http://dx.doi.org/10.1097/00010694-197012000-00008

[23] Chi, C.M., Zhao, C.W., Sun, X.J. and Wang, Z.C. (2011) Estimating Exchangeable Sodium Percentage from Sodium Adsorption Ratio and Salt-Affected Soil in the Songnen Plain of Northeast China. Pedosphere, 21, 271-276. http://dx.doi.org/10.1016/S1002-0160(11)60127-6

[24] Rashidi, M. and Seilsepour, M. (2008) Modeling of Soil Exchangeable Percentage Based on Soil Adsorption Ratio. Journal of Agriculture and Biological Science, 3, 22-26.

[25] Harron, W.R.A., Webster, G.R. and Cairns, R.R. (1983) Relationship between Exchangeable Sodium and Sodium Adsorption Ratio in a Sologetzic Soil Association. Canadian Journal of Soil Science, 63, 461-467. http://dx.doi.org/10.4141/cjss83-047

[26] Poonia, S.R. and Talibudeen, O. (1977) Sodium-Calcium Exchange Equilibrium in Salt Affected and Normal Soils. Journal of Soil Science, 28, 276-287. http://dx.doi.org/10.1111/j.1365-2389.1977.tb02236.x

[27] Corwin, D.L. and Lesch, S.M. (2005) Apparent Soil Electrical Conductivity Measurements in Agriculture. Computers Electronics in Agriculture, 46, 11-43. http://dx.doi.org/10.1016/j.compag.2004.10.005

[28] Hanson, B., Grattan, S.R. and Fulton, A. (1999) Agricultural Salinity and Drainage. University of California Irrigation Program. University of California, Davis.

[29] Rengasamy, P. and Olsson, K.A. (1991) Sodicity and Soil Structure. Australian Journal of Soil Research, 29, $935-952$. http://dx.doi.org/10.1071/SR9910935 
Scientific Research Publishing (SCIRP) is one of the largest Open Access journal publishers. It is currently publishing more than 200 open access, online, peer-reviewed journals covering a wide range of academic disciplines. SCIRP serves the worldwide academic communities and contributes to the progress and application of science with its publication.

Other selected journals from SCIRP are listed as below. Submit your manuscript to us via either submit@scirp.org or Online Submission Portal.
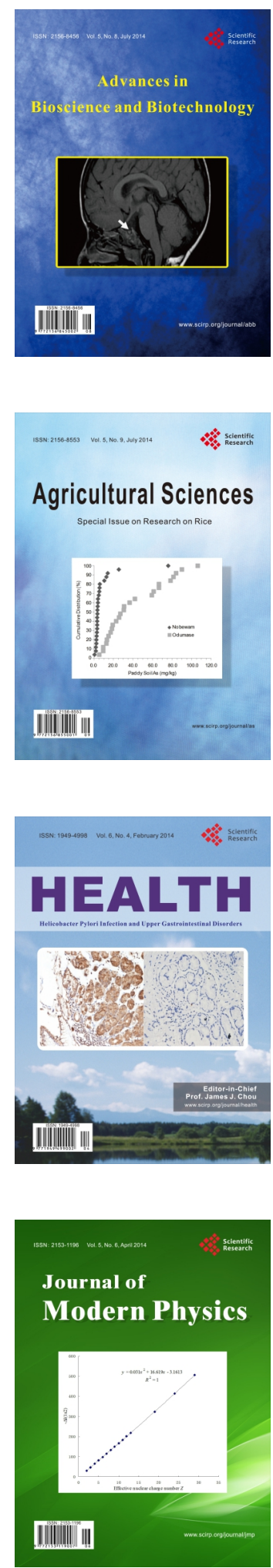
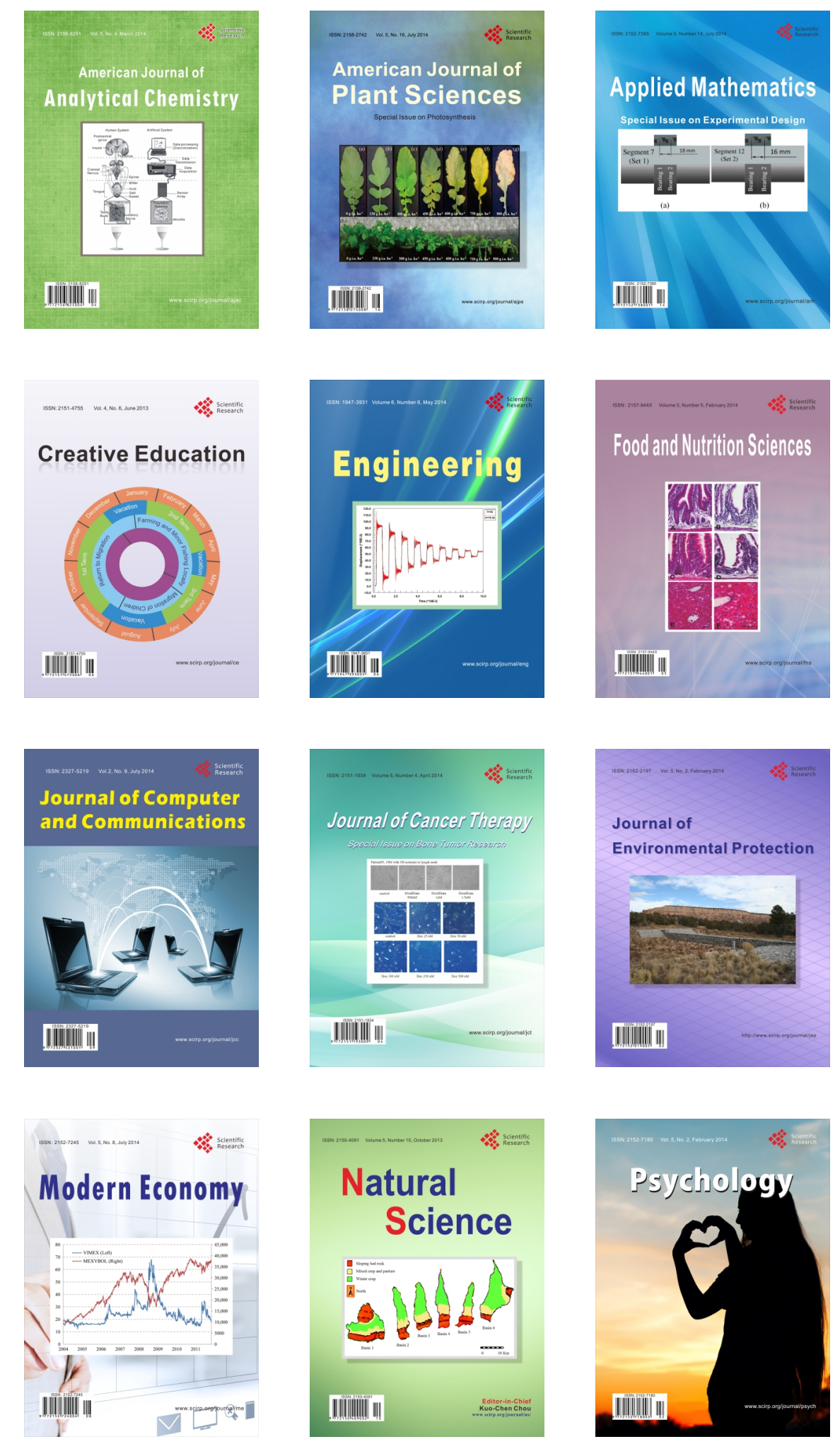